\title{
Correction to: TET Proteins and DNA Demethylation
}

\section{Ozren Bogdanovic and Michiel Vermeulen}

Correction to: Ozren Bogdanovic and Michiel Vermeulen (eds.), TET Proteins and DNA Demethylation: Methods and Protocols, Methods in Molecular Biology, vol. 2272, https://doi.org/10.1007/978-1-0716-1294-1

In the original version of this book, chapters 3,7 , and 17 were published non-open access. It has now been changed to open access under a CC BY 4.0 license and the copyright holder has been updated to "The Author(s)." This book has also been updated with these changes.

The updated online version of these chapters can be found at:

https://doi.org/10.1007/978-1-0716-1294-1_3

https://doi.org/10.1007/978-1-0716-1294-1_7

https://doi.org/10.1007/978-1-0716-1294-1_17

Ozren Bogdanovic and Michiel Vermeulen (eds.), TET Proteins and DNA Demethylation: Methods and Protocols, Methods in Molecular Biology, vol. 2272, https://doi.org/10.1007/978-1-0716-1294-1_18,

(C) Springer Science+Business Media, LLC, part of Springer Nature 2021 